\title{
Study some mechanical properties of self-compacting concrete with nano silica under severe saline environment conditions
}

\author{
Ghalib Habeeb ${ }^{1}$ and Zahraa Hashim ${ }^{1}$ \\ ${ }^{1}$ University of Babylon, Hilla, Iraq
}

\begin{abstract}
The main aim of this research is to evaluate the performance of Nano silica self-compacting concrete which is subjected to severe saline conditions that contain sulfates and chlorides at concentrations similar to those existing in the soils and ground water of the middle and southern parts of Iraq. For this purpose, ordinary and sulfate resistant Portland cement without and with 3\% Nano silica addition by weight of cementitious materials were used. Splitting tensile strength, flexural strength, static modulus of elasticity and ultrasonic pulse velocity were investigated for all exposure conditions and all types of mixes of selfcompacting concrete at ages of 28, 60,90, 120 and 180 days. Test results revealed that the inclusion of Nano Silica in concrete mixes improved clearly the mechanical properties of self-compacting concrete compared with reference concrete.
\end{abstract}

\section{Introduction}

Self-compacting concrete (SCC) has been defined as the concrete that does not require vibration for placing and compaction. It is capable to flow under its own weight, completely filling formwork and achieving full compaction even in the presence of congested reinforcement. The hardened concrete is dense, homogeneous and has the same engineering properties and durability as traditional vibrated concrete (European Project Group, 2005). SCC has been developed in Japan to get durable concrete structures due to increase of the homogeneity, which is attributed to improve the characteristics of SCC in fresh state; filling ability, passing ability and segregation resistance, in addition to enhancing the hardened properties of SCC. On the other hand, the durability of concrete structures is closely associated with the permeability of the surface layer. Therefore, the absence of compaction of the surface layer due to the difficulties of vibration in narrow spaces between the formwork and the re-bars, which can be characterized as a key factor of poor durability performance of reinforced concrete structures subjected to aggressive environments. Overcoming this was one of the main reasons for the original development of SCC in Japan (Singh and Thombre, 2013).

\section{Research significance}

Sulfate ions have been found in the groundwater and soil in the middle and southern parts of Iraq. In the regions of these parts, the concrete structures can be exposed to sulfate attack and likely suffer from two types of deterioration; loss of strength of the matrix resulting from degradation of calcium silicate hydrate (C-S-H), and volumetric change leading to expansion due to formation of gypsum or ettringite that leads to cracking. Protection against sulfate attack requires reducing the permeability of concrete; hence, the low permeability can prolong the service life of the structures that are subjected to severe exposure condition (AL-Rawi, 1985).

The key for enhancing the durability of SCC subjected to sever solution environments is a good compaction of microstructure with reducing the porosity of the mortar matrix and interfacial transition zone (ITZ) (Safiuddin et al., 2008). Thus, the addition of Nano Silica to concrete leads to improve the hardened properties of concrete because of its high pozzolanic activity and additional (C-S-H) are produced for generation more strength and reducing the free calcium hydroxide. In addition, the microstructure of concrete is improved and the permeability is reduced with utilizing Nano Silica (Nano filler and anti-leaching effects), the cohesiveness between the particles of concrete will be improved and segregation and bleeding will be decreased, thus, making concrete durable (Li, 2004), (Quercia et al., 2012).

\section{Materials}

\subsection{Cement}

Tasluja-Bazian Ordinary Portland cement (OPC) (ASTMC150 Type I) and Tasluja-Bazian sulfate resistance Portland cement (SRPC) (ASTMC150Type V) 
manufactured in Iraq were used for concrete mixes throughout the present work. This cement complied with the Iraqi specification (IQS, No.5:1984). The physical properties and chemical analysis of the cement used are given in Tables (1) and (2).

\subsection{Fine Aggregate (Sand)}

The fine aggregate from Al-Eakhadir region was used throughout this work. The test results indicate that the adopted fine aggregate conforms to the Iraqi specifications (IQS No.45/ 1984) for grading. It's some physical and chemical properties are shown in Table (3).

\subsection{Coarse Aggregate (Gravel)}

Rounded gravel of $14 \mathrm{~mm}$ maximum size from Al-Nebai quarry was used as a coarse aggregate in all mixes. Some physical properties and sulfate content of coarse aggregate are shown in Table (4).

\subsection{Water}

Potable water from the water-supply network system was used for both mixing and curing process of concrete.

\subsection{Superplasticizer}

To achieve high workability needed to produce SCC, super plasticizer known as Glenium 54 was used. Glenium 54 is free from chlorides and complies with (ASTM C494/ C494M, 2001) Type F. Table (5) shows the typical properties of Glenium 54.

\subsection{Micro Silica}

Micro silica, also known as Silica fume or condensed silica fume, is a byproduct of producing silicon metal or ferrosilicon alloys. It consists of silicon dioxide $\left(\mathrm{SiO}_{2}\right)$ usually more than $85 \%$ in non-crystalline (amorphous) form. Densified micro silica fume under commercial name (Sika ${ }^{\circledR}$ Fume S 92 D) had been used as replacement of cement with $5 \%$ by weight. Physical properties of silica fume are shown in Table (6).

\subsection{Nano Silica}

Nano Silica is not an industrial byproduct. It is manufactured under special conditions so as to have a high degree of purity and the well-defined range of diameter for the particles usually between $(10-50) \mathrm{nm}$.

Nano Silica used in this work was produced in China by precipitation method in powder form making Nano Silica to have a high degree of purity about $99.96 \%$ and diameter for the particles $(35 \mathrm{~nm})$. Table (7) presents its properties. X-ray diffraction (XRD) of Nano Silica was investigated as illustrated in Figure (1). As it can be seen, the XRD patterns show an approximately broad peak centered about $2 \Theta=20^{\circ}$ which demonstrates the amorphous structure of utilized Nano Silica. The utilized Nano Silica particles are expected to have high pozzolanic reactivity due to their amorphous structure.
Table 1. Physical Properties of Cement.

\begin{tabular}{|c|c|c|c|c|}
\hline & \multirow{2}{*}{ Physical properties } & \multirow{2}{*}{$\boldsymbol{O P C}$} & \multirow{2}{*}{$\boldsymbol{S R P C}$} & \multicolumn{2}{|c|}{$\begin{array}{c}\text { Limits of IQS } \\
\text { No. 5/1984) }\end{array}$} \\
\cline { 3 - 5 } & & & $\boldsymbol{O P C}$ & SRPC \\
\hline $\begin{array}{c}\text { Fineness, Blaine, } \\
\text { m }^{2} / \mathrm{kg}\end{array}$ & 334 & 360 & $\geq 230$ & $\geq 250$ \\
\hline $\begin{array}{c}\text { Setting Time } \\
\text { (Vicat's method): }\end{array}$ & & & \\
Initial (minute) & 190 & 150 & $\geq 45$ minute \\
Final (hours: minute) & $3: 30$ & $4: 30$ & $\leq 10$ hours \\
\hline $\begin{array}{c}\text { Compressive strength } \\
\text { (MPa) }\end{array}$ & & & \\
3days & 22.05 & 24.90 & $\geq 15$ \\
7days & 28 & 34.80 & $\geq 23$ \\
\hline
\end{tabular}

Table 2. Chemical Composition and Compounds of Cement.

\begin{tabular}{|c|c|c|c|c|}
\hline \multirow{2}{*}{$\begin{array}{c}\text { Chemical } \\
\text { Composition }\end{array}$} & \multicolumn{2}{|c|}{$\begin{array}{c}\text { Percent by } \\
\text { Weight of cement }\end{array}$} & \multicolumn{2}{|c|}{$\begin{array}{c}\text { Limits of } \\
(\text { IOS NO.5/1984) for }\end{array}$} \\
\hline & $O P C$ & SRPC & $O P C$ & $S R P C$ \\
\hline $\mathrm{CaO}$ & 61.37 & 62.26 & I & 1 \\
\hline $\mathrm{SiO}_{2}$ & 21.24 & 21.40 & 1 & 1 \\
\hline $\mathrm{Al}_{2} \mathrm{O}_{2}$ & 5.96 & 4.02 & 1 & 1 \\
\hline $\mathrm{Fe}_{2} \mathrm{O}_{2}$ & 3.32 & 4.64 & 1 & 1 \\
\hline $\mathrm{SO}_{3}$ & 2.30 & 2.25 & $\begin{array}{c}\leq 2.8 \% \\
\text { If } \\
\mathrm{C}_{\mathrm{a}} \mathrm{A}>5 \\
\%\end{array}$ & $\begin{array}{l}\leq 2.5 \% \text { If } \\
\mathrm{C}_{\mathrm{a}} \mathrm{A}<5 \%\end{array}$ \\
\hline $\mathrm{MgO}$ & 2.71 & 2.41 & $\leq 5 \%$ & $\leq 5 \%$ \\
\hline Free $\mathrm{CaO}$ & 0.84 & 1.06 & 1 & 1 \\
\hline L.O.I. & 1.69 & 1.5 & $\leq 4 \%$ & $\leq 4 \%$ \\
\hline I.R. & 0.62 & 0.79 & $\leq 1.5 \%$ & $\leq 1.5 \%$ \\
\hline L.S.F. & 0.87 & 0.9 & $\begin{array}{c}0.66- \\
1.02 \\
\end{array}$ & $0.66-1.02$ \\
\hline
\end{tabular}

\begin{tabular}{|c|c|c|c|c|}
\hline \multicolumn{3}{|c|}{$\begin{array}{c}\text { Main compounds } \\
\text { weight of cement }\end{array}$} \\
$\begin{array}{c}\text { Main compounds } \\
\text { (Bogue's equation) }\end{array}$ & \multicolumn{2}{|c|}{$\begin{array}{c}\text { (Borcentage by } \\
\text { weight }\end{array}$} & $\begin{array}{c}\text { Limits of } \\
\text { IQS } \\
\text { No.5/1984) } \\
\text { for }\end{array}$ \\
\cline { 2 - 5 } & OPC & SRPC & OPC & $\begin{array}{c}\text { SRP } \\
\text { C }\end{array}$ \\
\hline$\left(\mathrm{C}_{\mathrm{a}} \mathrm{S}\right)$ & 37.00 & 50.70 & $/$ & $/$ \\
\hline$\left(\mathrm{C}_{2} \mathrm{~S}\right)$ & 33.06 & 23.19 & $/$ & $/$ \\
\hline$\left(\mathrm{C}_{\mathrm{a}} \mathrm{A}\right)$ & 10.18 & 2.81 & $/$ & $\leq 3.5$ \\
\hline$\left(\mathrm{C}_{4} \mathrm{AF}\right)$ & 10.09 & 14.11 & $/$ & $/$ \\
\hline
\end{tabular}


Table 3. Physical properties and sulfate content of fine aggregate

\begin{tabular}{|c|c|c|}
\hline Properties & $\begin{array}{c}\text { Test } \\
\text { result }\end{array}$ & $\begin{array}{c}\text { Limits of Iraqi } \\
\text { Specification } \\
\text { No.4/1984 }\end{array}$ \\
\hline Specific gravity & 2.6 & ----- \\
\hline Fineness modulus & 2.51 & ----- \\
\hline Absorption, \% & 1.7 & ----- \\
\hline Passing sieve size $75 \mu \mathrm{m}, \%$ & 2.5 & $\begin{array}{c}\leq 5 \% \text { for natural } \\
\text { fine aggregate }\end{array}$ \\
\hline Sulfate content $\left(\mathrm{SO}_{3}\right), \%$ & 0.25 & $\leq 0.5 \%$ \\
\hline
\end{tabular}

Table 4. Physical Properties and Sulfate Content of Coarse Aggregate.

\begin{tabular}{|c|c|c|}
\hline Properties & $\begin{array}{c}\text { Test } \\
\text { result }\end{array}$ & $\begin{array}{c}\text { Limits of Iraqi } \\
\text { Specification } \\
\text { No.45/1984 }\end{array}$ \\
\hline Specific gravity & 2.65 & ---- \\
\hline $\begin{array}{c}\text { Dry rodded density } \\
\left(\mathrm{kg} / \mathrm{m}^{\mathrm{a}}\right)\end{array}$ & 1640 & ---- \\
\hline Absorption, \% & 0.8 & ----- \\
\hline Sulfate content $\left(\mathrm{SO}_{\mathrm{a}}\right), \%$ & 0.02 & $\leq 0.1 \%$ \\
\hline Passing sieve size $75 \mu_{\mathrm{m}}, \%$ & 0.8 & $\leq 3 \%$ \\
\hline
\end{tabular}

Table 5. Typical Properties of Glenium 54.

\begin{tabular}{|c|c|}
\hline Form & Whitish to straw colored liquid \\
\hline Relative density & 1.07 at $25^{\circ} \mathrm{C}$ \\
\hline $\begin{array}{c}\text { Chloride } \\
\text { content }\end{array}$ & Free \\
\hline $\mathrm{pH}$ & 6.5 \\
\hline Storage & $\begin{array}{c}\text { Should be stored in original } \\
\text { containers and at above } 5^{\square} \mathrm{C} . \text { if } \\
\text { frozen, gradually thaw and agitate } \\
\text { until completely reconstituted. }\end{array}$ \\
\hline
\end{tabular}

Table 6. Physical Properties of SF.

\begin{tabular}{|c|c|c|}
\hline Physical properties & SF & $\begin{array}{c}\text { Limit of specification } \\
\text { requirements } \text { ASTM } \\
\text { C-1240 }\end{array}$ \\
\hline $\begin{array}{c}\text { Specific surface, min, } \\
\left(\mathrm{m}^{2} / g\right)\end{array}$ & 24 & $\geq 15$ \\
\hline $\begin{array}{c}\text { Accelerated pozzolanic } \\
\text { activity index }(\%) \text { at } 7 \\
\text { days }\end{array}$ & 131 & $\geq 105$ \\
\hline Bulk density $\left(\mathrm{kg} / \mathrm{m}^{\mathrm{a}}\right)$ & 400 & ----- \\
\hline $\begin{array}{c}\text { Percent retained on } 45 \mu \mathrm{m} \\
(\text { No.325) sieve, } \max , \%\end{array}$ & 5 & $\leq 10$ \\
\hline
\end{tabular}

Table 7. Properties of NS.

\begin{tabular}{|c|c|}
\hline Properties & Description \\
\hline $\mathrm{SiO}_{2} \%$ & 99.96 \\
\hline Physical form & Powder \\
\hline Color & White \\
\hline Particle size, $\mathrm{mm}$ & 35 \\
\hline Surface area $\left(\mathrm{m}^{2} / \mathrm{g}\right)$ & 270 \\
\hline
\end{tabular}

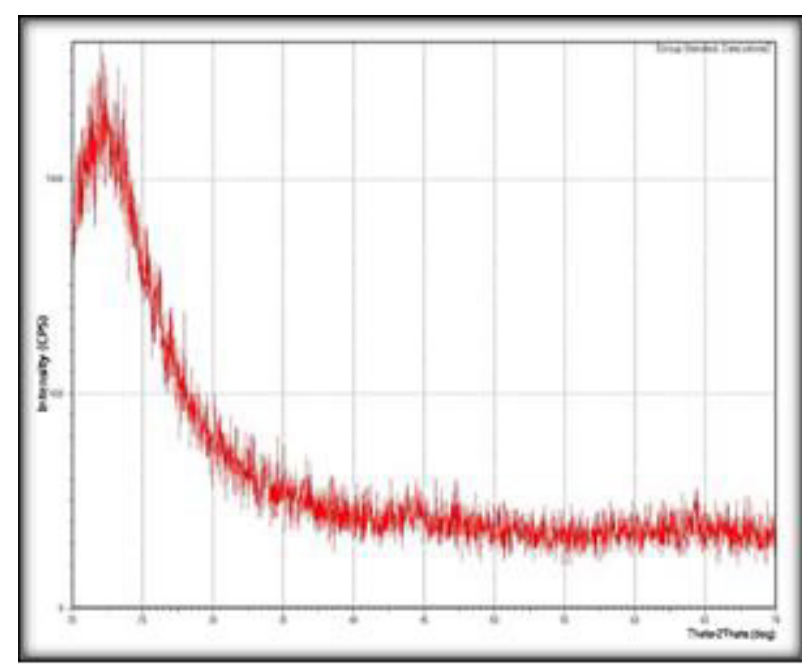

Fig. 1. X-ray diffraction patterns of NS.

\section{Concrete mixes}

Four mixes were made, all based on the same control mixture. These mixes were divided into two series each one with different type of cement (I or V). The concrete mixes were designed according to (European Project Group, 2005). The mix proportions were shown in Table (8).

\section{Mixing placing and curing procedures}

Mixing process was conducted in pan mixer with a capacity of $0.05 \mathrm{~m}^{2}$. The $3 / 4$ dosage of superplasticizer was added to mixing water and mixed about 30 second in a small pan mixing separately from other material then the Nano Silica was stirred with this solution and mixed about 3 minutes in order to disperse uniformly and avoid agglomerations of Nano Silica since it has a high surface energy before 2 minutes from the end of previous mixing, the cement and silica fume had been added in pan mixer and mixed for 1 minute in dry state. The fine aggregate was added to the drying materials and mixed for 1 minute. The prepared solution of (superplasticizer, water and Nano Silica) was added and mixed for 3 minutes. Thereafter, gravel was added and mixed for 1 minute, 
then the remaining dosage $1 / 4$ of super plasticizer is added and mixed for 2 minutes. The mixture is then discharged, tested and placed. The total time of mixing process was about 8 minutes.

All specimens were demolded after 24 hours and placed in tap water for 28 days as initial curing. After 28 days of curing in tap water, all the concrete specimens were divided into three groups. The first group was partially submerged in $\left(\mathrm{SO}_{4}{ }^{--}+\mathrm{Cl}^{-}\right)$solution, the second group was partially submerged in $\left(\mathrm{SO}_{4}{ }^{-}\right)$solution, while the third group was submerged in tap water for comparison. These aggressive solutions at concentration identical to those existing in soil and ground water of the middle and southern parts of Iraq.

\section{Preparation of aggressive solutions}

The salts of sulfates and chlorides used in preparing the solutions and providing the suitable concentrations of the ions were pure $\mathrm{MgSO}_{4} \cdot 7 \mathrm{H}_{2} \mathrm{O}, \mathrm{Na}_{2} \mathrm{SO}_{4}, \mathrm{CaCl}_{2} \cdot 2 \mathrm{H}_{2} \mathrm{O}$ and $\mathrm{NaCl}$. Tables (9) and (11) show the types and concentrations of salts that used. Tables (10) and (12) illustrate the actual inions and cations provided by such salts.

Table 8. The main details of SCC Mixes used in the present study.

\begin{tabular}{|c|c|c|c|c|c|c|c|c|c|}
\hline 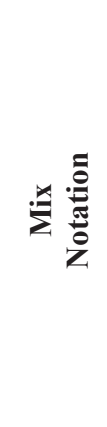 & 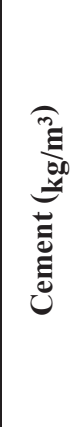 & 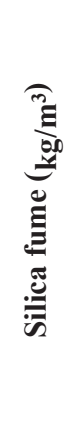 & 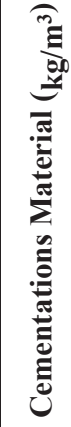 & 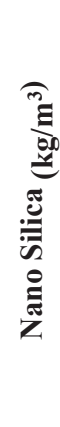 & ت & 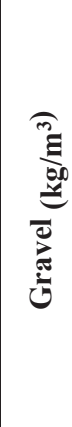 & के & 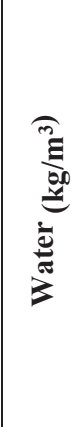 & 苞 \\
\hline $\begin{array}{c}\text { OPC- } \\
0 \% \text { NS } \\
\text { (OR) }\end{array}$ & 475 & 25 & 500 & --- & 780 & 820 & 0.7 & 180 & 0.36 \\
\hline $\begin{array}{l}\text { OPC- } \\
3 \% N S \\
\text { (ON3) }\end{array}$ & 475 & 25 & 500 & 15 & 780 & 820 & 2.0 & 180 & 0.35 \\
\hline $\begin{array}{c}\text { SRPC } \\
- \\
0 \% \mathrm{NS} \\
\text { (SR) }\end{array}$ & 475 & 25 & 500 & --- & 780 & 820 & 0.7 & 180 & 0.36 \\
\hline $\begin{array}{c}\text { SRPC } \\
- \\
3 \% N S \\
\text { (SN3) }\end{array}$ & 475 & 25 & 500 & 15 & 780 & 820 & 2.0 & 180 & 0.35 \\
\hline
\end{tabular}

Table 9. Salts types \& concentration used in sulfate solution

\begin{tabular}{|c|c|c|c|c|}
\hline \multirow{2}{*}{$\begin{array}{c}\text { Types of } \\
\text { salts }\end{array}$} & \multirow{2}{*}{$\begin{array}{c}\text { Chemical } \\
\text { form }\end{array}$} & \multicolumn{2}{|c|}{ Concentration } & \multirow{2}{*}{$\begin{array}{c}\text { Salt content } \% \text { by } \\
\text { wt. of cement }\end{array}$} \\
\hline & & ppm & $g m / l$ & \\
\hline \multirow{2}{*}{ Sulfate salts } & $\mathrm{MgSO}_{4} \cdot 7 \mathrm{H}_{2} \mathrm{O}$ & 15000 & 15 & 1.5 \\
\hline & $\mathrm{Na}_{2} \mathrm{SO}_{4}$ & 3250 & 3.25 & 0.325 \\
\hline
\end{tabular}

Table 10. Ions concentration of ions used in sulfate solution.

\begin{tabular}{|c|c|c|c|}
\hline \multicolumn{2}{|c|}{ Anions } & \multicolumn{2}{c|}{ Cations } \\
\hline Type & $\begin{array}{c}\text { Concentration, } \\
p p m\end{array}$ & Type & $\begin{array}{c}\text { Concentration, } \\
\text { ppm }\end{array}$ \\
\hline \multirow{2}{*}{$\mathrm{SO}_{4} \because$} & 8041 & $\mathrm{Mg}^{++}$ & 1480.5 \\
\cline { 3 - 4 } & & $\mathrm{Na}^{+}$ & 1053 \\
\hline
\end{tabular}

Table 11. Salts types \& concentration used in sulfate-chloride solution.

\begin{tabular}{|c|c|c|c|}
\hline \multicolumn{2}{|c|}{ Anions } & \multicolumn{2}{c|}{ Cations } \\
\hline \multirow{2}{*}{ Type } & $\begin{array}{c}\text { Concentration, } \\
\text { ppm }\end{array}$ & Type & $\begin{array}{c}\text { Concentration, } \\
\text { ppm }\end{array}$ \\
\hline \multirow{2}{*}{$\mathrm{SO}_{4}^{-{ }^{-}}$} & 8041 & $\mathrm{Mg}^{++}$ & 1480.5 \\
\cline { 4 - 4 } $\mathrm{Cl}^{-}$ & 33718.9 & $\mathrm{Na}^{+}$ & 20713 \\
\cline { 4 - 4 } & & $\mathrm{Ca}^{++}$ & 1908.2 \\
\hline
\end{tabular}

Table 12. Ions concentration used in sulfate-chloride solution.

\begin{tabular}{|c|c|c|c|c|}
\hline \multirow{2}{*}{$\begin{array}{l}\text { Types of } \\
\text { salts }\end{array}$} & \multirow{2}{*}{$\begin{array}{l}\text { Chemical } \\
\text { form }\end{array}$} & \multicolumn{2}{|c|}{ Concentration } & \multirow{2}{*}{$\begin{array}{c}\text { Salt content \% by } \\
\text { wt. of cement }\end{array}$} \\
\hline & & $p p m$ & $g m / l$ & \\
\hline \multirow{2}{*}{ Sulfate salts } & $\mathrm{MgSO}_{4} \cdot 7 \mathrm{H}_{2} \mathrm{O}$ & 15000 & 15 & 1.5 \\
\hline & $\mathrm{Na}_{2} \mathrm{SO}_{4}$ & 3250 & 3.25 & 0.325 \\
\hline \multirow{2}{*}{$\begin{array}{l}\text { Chloride } \\
\text { salts }\end{array}$} & $\mathrm{CaCl}_{2} \cdot 2 \mathrm{H}_{2} \mathrm{O}$ & 7000 & 7 & 0.7 \\
\hline & $\mathrm{NaCl}$ & 50000 & 50 & 5 \\
\hline
\end{tabular}

\section{Tests of hardened concrete properties}

The hardened properties of concrete which were studied: splitting tensile strength, flexural strength, modulus of elasticity and ultrasonic pulse velocity test (U.P.V.). After the concrete had been cast and cured, splitting tensile strength of (104) cylinders with dimensions $(100 \times 200) \mathrm{mm}$, flexural strength of (104) prisms with dimensions $(100 \times 100 \times 400) \mathrm{mm}$, static modulus of elasticity of (104) cylinders with dimensions $(150 \times 300) \mathrm{mm}$ and U.P.V. of (156) cubes with an edge length (100)mm were examined. The average of two specimens was taken for each test except U.P.V., the average of three cubes was taken.

\section{Results and discussion}

\subsection{Splitting Tensile strength}

The results of splitting tensile strength of SCC specimens cured in tap water and other Aggressive solution exposer are shown in Table (13) and Figure $(2-a, b, c)$. All specimens cured in tap water exhibited a continuous 
development in splitting tensile strength with age progress. While SCC specimens containing Nano Silica (ON3 and $\mathrm{SN} 3$ ) exposed to $\left(\mathrm{SO}_{4}{ }^{--}+\mathrm{Cl}^{-}\right)$solution revealed the increment in splitting tensile strength up to 180 days of exposure, due to the presence of Nano Silica, which has increased the strength of concrete. while the reference SCC specimens (without Nano Silica) reveal the increment in splitting tensile strength up to 90 days and 120 days of exposure for (OR and SR) concretes respectively; after that a decrease in strength occurred up to 180 days. This reduction is due to the attack of sulfate ions, which leads to form the gypsum and ettringite that leading to expansion, spalling, cracking and loss of strength of concrete; thereby the deterioration in concrete occurs.

As illustrated in Table (13) and Figure (2-c), SCC specimens with Nano Silica (SN3) exposed to $\left(\mathrm{SO}_{4}{ }^{--}\right.$) solution offered the increment in splitting tensile strength up to 180 days of exposure, due to the presence of Nano Silica. While $(\mathrm{ON} 3)$ specimens exposed to $\left(\mathrm{SO}_{4}{ }^{--}\right)$ solution show that the increases in splitting tensile strength is stopped in 120 days of exposure; then a stability in strength is observed at 180 days, because of the presence of pure sulfate ions and the use of OPC in Nano Silica concrete. In contrast for (OR and SR) concretes, the increment in splitting tensile strength is observed up to 90 days and 120 days of exposure respectively; then a decrease in strength is occurs up to 180 days.

Table 13. Results of Splitting Tensile Strength of SCC Mixes.

\begin{tabular}{|c|c|c|c|c|c|}
\hline \multicolumn{6}{|c|}{ Splitting tensile strength (MPa) (Tap water) } \\
\hline Mix Designation & $\begin{array}{c}\text { Before exposure } \\
\text { at } 28 \text { days }\end{array}$ & $\begin{array}{c}60 \\
\text { days }\end{array}$ & $\begin{array}{c}90 \\
\text { days }\end{array}$ & $\begin{array}{r}120 \\
\text { days }\end{array}$ & $\begin{array}{r}180 \\
\text { days }\end{array}$ \\
\hline OPC- $0 \% N S$ (OR) & 4.24 & 5.15 & 5.57 & 5.78 & 6.08 \\
\hline OPC- 3\%NS (ON3) & 6.06 & 7.17 & 7.60 & 7.86 & 8.25 \\
\hline SRPC- 0\%NS (SR) & 5.00 & 6.29 & 7.13 & 7.58 & 7.94 \\
\hline SRPC- 3\%NS (SN3) & 6.73 & 8.23 & 8.96 & 9.22 & 9.90 \\
\hline \multicolumn{6}{|c|}{ Splitting tensile strength $(\mathrm{MPa})\left(\mathrm{SO}_{4}^{--}+\mathrm{Cl}^{-}\right)$} \\
\hline Mix Designation & $\begin{array}{c}\text { Before exposure } \\
\text { at } 28 \text { days }\end{array}$ & $\begin{array}{c}60 \\
\text { davs }\end{array}$ & $\begin{array}{c}90 \\
\text { davs }\end{array}$ & $\begin{array}{l}120 \\
\text { davs }\end{array}$ & $\begin{array}{r}180 \\
\text { davs }\end{array}$ \\
\hline OPC- $0 \% N S$ (OR) & 4.24 & 4.74 & 4.97 & 4.91 & 4.55 \\
\hline OPC- $3 \%$ NS (ON3) & 6.06 & 7.00 & 7.35 & 7.56 & 7.69 \\
\hline SRPC- 0\%NS (SR) & 5.00 & 6.04 & 6.41 & 6.68 & 6.63 \\
\hline SRPC- 3\%NS (SN3) & 6.73 & 8.16 & 8.69 & 9.07 & 9.61 \\
\hline \multicolumn{6}{|c|}{ Splitting tensile strength (MPa) $\left.\mathrm{SO}_{4}^{--}\right)$} \\
\hline Mix Designation & $\begin{array}{c}\text { Before exposure at } 28 \\
\text { days }\end{array}$ & $\begin{array}{c}60 \\
\text { days }\end{array}$ & $\begin{array}{c}90 \\
\text { days }\end{array}$ & $\begin{array}{l}120 \\
\text { days }\end{array}$ & $\begin{array}{r}180 \\
\text { days }\end{array}$ \\
\hline OPC- $0 \% N S$ (OR) & 4.24 & 4.60 & 4.63 & 4.24 & 3.97 \\
\hline OPC- $3 \% \mathrm{NS}$ (ON3) & 6.06 & 6.90 & 7.27 & 7.48 & 7.48 \\
\hline SRPC- 0\%NS (SR) & 5.00 & 5.76 & 6.14 & 6.22 & 5.79 \\
\hline SRPC- 3\%NS (SN3) & 6.73 & 8.03 & 8.59 & 8.91 & 9.42 \\
\hline
\end{tabular}
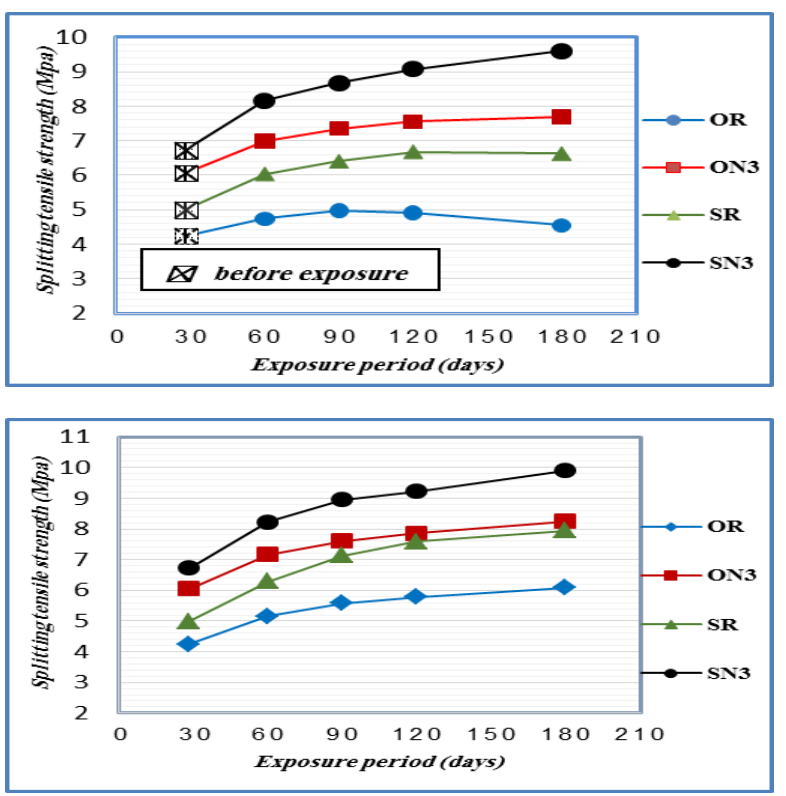

(a) Tap water

(b) $\left(\mathrm{SO}_{4}{ }^{--}+\mathrm{Cl}^{-}\right)$solution.

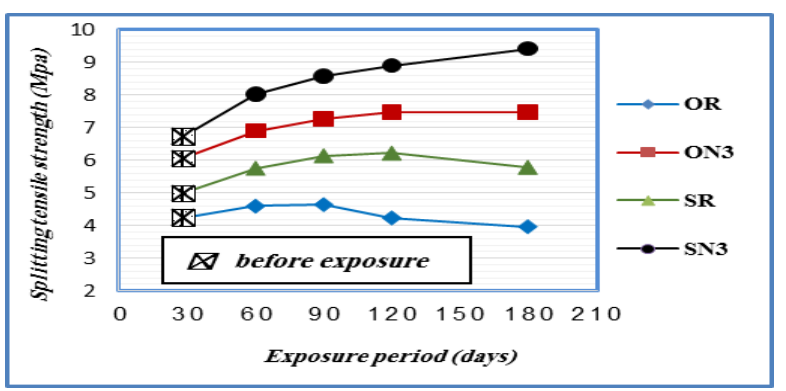

Fig. 2. Splitting Tensile Strength Development of SCC Mixes Exposed to various exposure conditions.

This reduction is caused by the existence of pure sulfate ions, which will consume more amount of portlandite $(\mathrm{CH})$ from hydration of cement and $\mathrm{C}_{3} \mathrm{~A}$ compared with combined sulfate ions; thereby, the gypsum and ettringite are formed. Also, the presence of $\mathrm{Mg}^{+2}$ cations associated with sulfate salts, that convert a further portlandite in the case of pure sulfate attack (when compared with available portlandite in combined sulfate with chloride solution) to gypsum by the simultaneous formation of Brucite (magnesium hydroxide), which is insoluble and reduces the $\mathrm{pH}$ of the system. In the absence of the portlandite, (C-S-H) gel is no longer stable and is also attacked by magnesium sulfate, $(\mathrm{C}-\mathrm{S}-\mathrm{H})$ gel will be converted to a cohesion less, porous, reticulated magnesium silicate hydrate (M-S-H) gel, resulting in loss of cohesiveness and reduction in strength, as reported (Asrar et al., 1997), (Prasad et al., 2006).

The reason of Nano silica reduces the loss in splitting tensile strength of SCC specimens exposed to aggressive solution solutions and improves the splitting tensile strength of SCC specimens cured in tap water is attributed to Nano Silica enhances the tensile strength of hardened cement mortar by two mechanisms. The first of 
which is the packing effect of Nano particles as filler hardened microstructure of cement mortar and thus increasing its density as well as the strength. The second is the pozzolanic effect, Nano Silica reacts with $\mathrm{Ca}(\mathrm{OH})_{2}$ and produces $\mathrm{C}-\mathrm{S}-\mathrm{H}$. Therefore, it reduces the formation of gypsum and ettringite which leads to reduce the internal tensile stress forming from expansion of ettringite so increasing tensile strength. The same conclusion is reported as (Sobolev et al., 2006), (Qing et al, 2007).

From the results, it is also clear that SRPC mixes have higher splitting tensile strength than OPC mixes at all ages and for all exposure conditions and therefore, enhancing sulfate resistance is achieved. This behavior is due to a low content of $\mathrm{C}_{3} \mathrm{~A}$ compound and high ratio of $\mathrm{C}_{3} \mathrm{~S} / \mathrm{C}_{2} \mathrm{~S}$ in SRPC than OPC. Also, it is clear that combined sulfate attack reduces the deterioration in splitting tensile strength than pure sulfate. These trends were also reported by (Al-Amoudi et al., 1995).

\subsection{Flexural Strength}

The results of flexural strength of SCC specimens are illustrated in Table (14) and Figures (3- a, b, c). The data in Table (14) and Figure (3-a) indicate that all specimens cured in tap water demonstrate a continuous increasing in flexural strength with age. While the specimens exposed to $\left(\mathrm{SO}_{4}{ }^{--}+\mathrm{Cl}^{-}\right)$solution which contained Nano Silica (ON3 and SN3) exhibit an improvement in flexural strength up to 180 days of exposure, relative to corresponding reference specimens without Nano Silica (OR and SR) which show a continuous increase in flexural strength up to 90 and 120-days of exposure respectively. Those results are also summarized in Figure (3-b).

On the other hand, all SCC specimens which were subjected to $\left(\mathrm{SO}_{4}{ }^{-{ }^{-}}\right)$solution have the same behavior that in $\left(\mathrm{SO}_{4}{ }^{--}+\mathrm{Cl}^{-}\right)$solution, except for (OR) specimens which exhibit a noticeable strength increase at 60 days of exposure, beyond this period a reduction in flexural strength is observed. This increase in flexural strength at 60 days may be attributed to the filling up of pores by reactions between products and crystallization of salts. This phenomenon has also been stated by (Ganjian and Pouya, 2005).

The enhancement in flexural strength for Nano Silica concretes can be mainly due to addition of Nano Silica particles producing a homogeneous microstructure, characterized by compact and small sized CSH gel. So, a denser ITZ was produced that means the bonding strength at the interface zone is increased and the formation of micro cracking is decreased. Hence, the micro cracking initiation occurs at a higher stress level. The addition of Nano Silica caused a refinement of the microstructures (less interconnected pore structure) and induced precipitation of small sizes $\mathrm{C}-\mathrm{S}-\mathrm{H}$ gel having high stiffness. The improvement of the microstructure was reflected by the mechanical properties due to the fact that the pozzolanic gel structure presents better mechanical properties than the C-S-H gel precipitated in standard OPC concrete (Sobolev et al., 2006) and (Khanzadi et al.,2010). As a results of Sulfate attack, the results also material into interstitial spaces inside the skeleton of show a decrease in flexural strength for SCC mixes immersed in saline solutions. It is clear that the deterioration in flexural strength for SCC specimens exposed to pure sulfate solution is more than that exposed to combined sulfate solution. Also, the SRPC mixes showed higher flexural strength than OPC mixes.

Table 14. Results of Flexural Strength of SCC Mixes.

\begin{tabular}{|c|c|c|c|c|c|}
\hline \multicolumn{6}{|c|}{ Flexural strength (MPa) (Tap water) } \\
\hline Mix & $\begin{array}{c}\text { Before exposure } \\
\text { at } 28 \text { days }\end{array}$ & $\begin{array}{c}60 \\
\text { days }\end{array}$ & $\begin{array}{c}90 \\
\text { days }\end{array}$ & $\begin{array}{c}120 \\
\text { days }\end{array}$ & $\begin{array}{c}180 \\
\text { days }\end{array}$ \\
\hline $\begin{array}{c}\text { OPC- } 0 \% \mathrm{NS} \\
\text { (OR) }\end{array}$ & 8.41 & 9.81 & 10.38 & 10.84 & 11.25 \\
\hline $\begin{array}{c}\text { OPC- } 3 \% \mathrm{NS} \\
(\mathrm{ON} 3)\end{array}$ & 11.80 & 13.07 & 13.81 & 14.33 & 14.54 \\
\hline $\begin{array}{l}\text { SRPC- 0\%NS } \\
\text { (SR) }\end{array}$ & 9.46 & 11.73 & 12.49 & 12.94 & 13.54 \\
\hline $\begin{array}{l}\text { SRPC- 3\%NS } \\
\text { (SN3) }\end{array}$ & 13.08 & 14.42 & 15.63 & 16.00 & 16.40 \\
\hline \multicolumn{6}{|c|}{ Flexural strength $(\mathrm{MPa})\left(\mathrm{SO}_{4}^{--}+\mathrm{Cl}^{-}\right)$} \\
\hline Mix & $\begin{array}{c}\text { Before exposure } \\
\text { at } 28 \text { days }\end{array}$ & $\begin{array}{c}60 \\
\text { days }\end{array}$ & $\begin{array}{c}90 \\
\text { days }\end{array}$ & $\begin{array}{c}120 \\
\text { days }\end{array}$ & $\begin{array}{l}180 \\
\text { days }\end{array}$ \\
\hline $\begin{array}{c}\text { OPC- 0\%NS } \\
(\mathrm{OR})\end{array}$ & 8.41 & 9.01 & 9.44 & 9.38 & 8.85 \\
\hline $\begin{array}{c}\text { OPC- 3\%NS } \\
\text { (ON3) }\end{array}$ & 11.80 & 12.91 & 13.34 & 413.64 & 13.77 \\
\hline \begin{tabular}{|c|} 
SRPC- 0\%NS \\
(SR)
\end{tabular} & 9.46 & 11.24 & 12.04 & 12.23 & 12.12 \\
\hline \begin{tabular}{|c|} 
SRPC- 3\%NS \\
(SN3)
\end{tabular} & 13.08 & 14.34 & 15.45 & 15.76 & 16.20 \\
\hline \multicolumn{6}{|c|}{ Flexural strength $(\mathrm{MPa})\left(\mathrm{SO}_{4}^{--}\right)$} \\
\hline $\begin{array}{c}\text { Mix } \\
\text { Designation }\end{array}$ & $\begin{array}{c}\text { Before exposure at } \\
28 \text { days }\end{array}$ & $\begin{array}{c}60 \\
\text { days }\end{array}$ & $\begin{array}{c}90 \\
\text { days }\end{array}$ & $\begin{array}{c}120 \\
\text { days }\end{array}$ & $\begin{array}{c}180 \\
\text { days }\end{array}$ \\
\hline $\begin{array}{c}\text { OPC- } 0 \% \mathrm{NS} \\
(\mathrm{OR})\end{array}$ & 8.41 & 9.34 & 9.33 & 9.14 & 8.27 \\
\hline \begin{tabular}{|c|} 
OPC- 3\%NS \\
(ON3)
\end{tabular} & 11.80 & 12.80 & 13.00 & 13.44 & 13.48 \\
\hline \begin{tabular}{|c|} 
SRPC- 0\%NS \\
(SR)
\end{tabular} & 9.46 & 11.00 & 11.89 & 12.11 & 12.00 \\
\hline \begin{tabular}{|c|} 
SRPC- 3\%NS \\
(SN3)
\end{tabular} & 13.08 & 14.34 & 15.33 & 15.50 & 16.06 \\
\hline
\end{tabular}

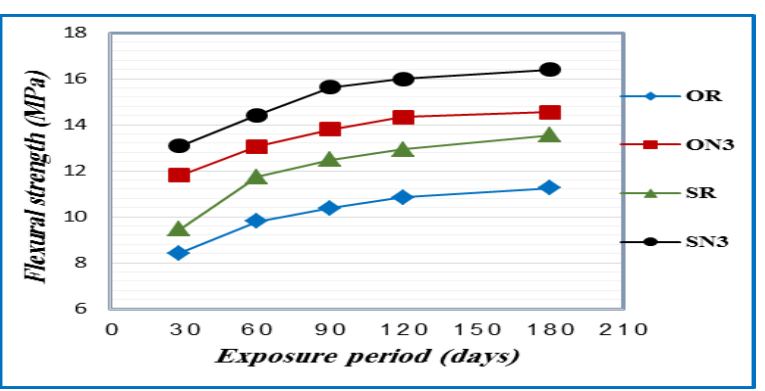

(a)Tap water 


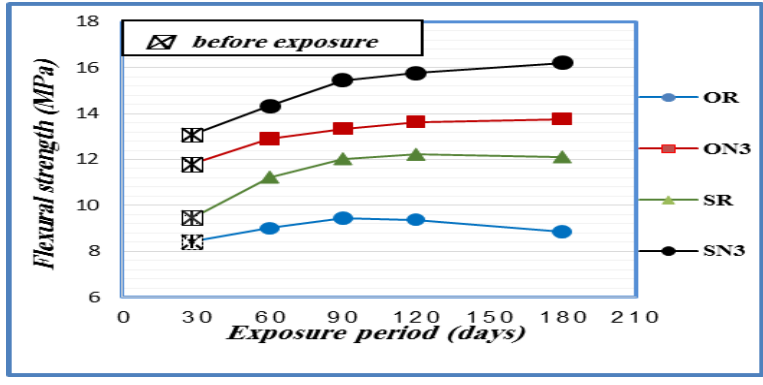

(b) $\left(\mathrm{SO}_{4}{ }^{--}+\mathrm{Cl}^{-}\right)$solution

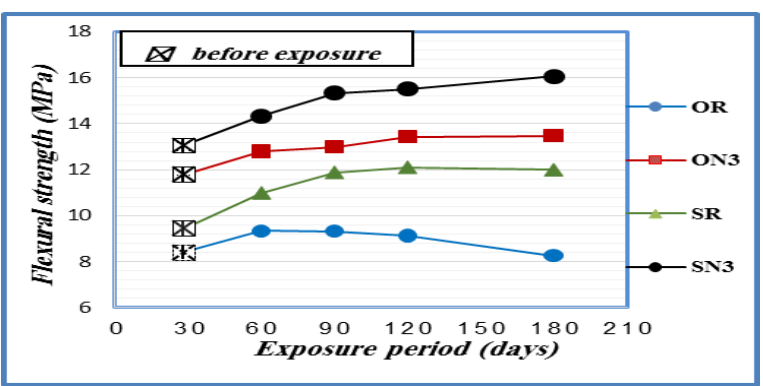

(c) $\left(\mathrm{SO}_{4}{ }^{--}\right)$solution.

Fig. 3. Flexural Strength Development of SCC Mixes Exposed to various exposure conditions.

\subsection{Static Modulus of Elasticity}

The results of modulus of elasticity of SCC specimens cured in tap water are illustrated in Table (15) and plotted in Figure (4-a). While, the results for both sulfate exposure conditions for all SCC specimens are also shown in Table (15) and Figures (4- b and c). It is observed from these results that SCC specimens tends to have lower modulus of elasticity, the static modulus of elasticity of SCC specimens ranged between (30.2348.28) GPa. This behavior is due to the high content of paste and low content of aggregate at SCC. From these results, it is observed that all SCC specimens exposed to either $\left(\mathrm{SO}_{4}^{--}+\mathrm{Cl}^{-}\right)$solution or $\left(\mathrm{SO}_{4}^{--}\right)$solution exhibited the percentages of decrease in elastic modulus at all ages of the test compared with those cured in tap water. The reason of this decrease is attributed to the decrease in modulus of elasticity of the matrix caused by the degeneration of the interfacial bond strength between bulk cement paste and aggregate.

Generally, it is clear that the decrease in elastic modulus in SRPC mixes was less than that in OPC mixes. This is due to low content of $\mathrm{C}_{3} \mathrm{~A}$ compound and high ratio of $\mathrm{C}_{3} \mathrm{~S} / \mathrm{C}_{2} \mathrm{~S}$ in SRPC compared with those in OPC. Also, it is observed that the decrease in the modulus of elasticity for $\mathrm{SCC}$ mixes exposed to $\left(\mathrm{SO}_{4}^{-}{ }^{-}\right)$solution is higher than those subjected to $\left(\mathrm{SO}_{4}^{-}+\mathrm{Cl}^{-}\right)$solution, which may be due to: (i) the increased solubility of ettringite and gypsum in chloride-bearing solution Which can reduce the amount of sulfate products formed in cement paste, (ii) the ettringite formed in the sulfate chloride solution being less expansive, and (iii) the higher diffusivity of chloride ions compared with sulfate ions permittings the chloride ions to react with $\mathrm{C}_{3} \mathrm{~A}$ to form Freidel's salt, which will reduce the conventional sulfate attack. This agrees with (Al-Amoudi et al., 1995). As well as, it is also clear that Nano silica addition reduces the reduction in modulus of elasticity at all SCC specimens. On the other hand, the modulus of elasticity increases with adding Nano Silica at all mixes and at all ages.

Table 15. Results of static modulus of elasticity of scc mixes.

\begin{tabular}{|c|c|c|c|c|c|c|c|}
\hline \multicolumn{8}{|c|}{ Modulus of Elasticity (GPa) (Tap water) } \\
\hline Mix & $\begin{array}{l}\text { Before } \\
\text { at } 28 \\
\text { days }\end{array}$ & $\begin{array}{c}60 \\
\text { days }\end{array}$ & 90 days & $\begin{array}{l}120 \\
\text { day }\end{array}$ & \multicolumn{3}{|c|}{180 days } \\
\hline \begin{tabular}{|c|} 
OPC- \\
$0 \% \mathrm{NS}(\mathrm{OR})$
\end{tabular} & 31.30 & 33.21 & 35.21 & 36.0 & & \multicolumn{2}{|c|}{36.65} \\
\hline \begin{tabular}{|c|} 
OPC- \\
$3 \% \mathrm{NS}$ \\
$(\mathrm{ON} 3)$ \\
\end{tabular} & 39.00 & 40.40 & 42.75 & 43.6 & & \multicolumn{2}{|c|}{44.28} \\
\hline $\begin{array}{c}\text { SRPC- } \\
0 \% \mathrm{NS} \text { (SR) }\end{array}$ & 33.78 & 35.71 & 38.36 & 39.5 & & \multicolumn{2}{|c|}{40.74} \\
\hline $\begin{array}{l}\text { SRPC- } \\
3 \% \mathrm{NS} \\
(\mathrm{SN} 3) \\
\end{array}$ & 40.83 & 43.12 & 45.78 & 46.9 & & \multicolumn{2}{|c|}{48.28} \\
\hline \multicolumn{8}{|c|}{ Modulus of Elasticity $(\mathrm{GPa})\left(\mathrm{SO}_{4}^{--}+\mathrm{Cl}^{-}\right)$} \\
\hline Mix & $\begin{array}{c}\text { Before } \\
\text { at } 28 \\
\text { days } \\
\end{array}$ & $\begin{array}{c}60 \\
\text { days }\end{array}$ & 90 days & $\begin{array}{l}120 \\
\text { day }\end{array}$ & \multicolumn{3}{|c|}{180 days } \\
\hline \begin{tabular}{|c|} 
OPC- \\
$0 \% \mathrm{NS}(\mathrm{OR})$
\end{tabular} & 31.30 & 32.19 & 33.06 & 32.6 & & \multicolumn{2}{|c|}{30.67} \\
\hline \multicolumn{3}{|c|}{ OPC- $3 \% \mathrm{NS}$ (ON3) } & 39.00 & \multicolumn{4}{|c|}{40.1842 .3343 .0043 .17} \\
\hline \multicolumn{3}{|c|}{ SRPC- $0 \%$ NS (SR) } & 33.78 & 35.40 & 37.47 & \multicolumn{2}{|c|}{\begin{tabular}{lll|l|}
47 & 37.64 & 36.90 \\
\end{tabular}} \\
\hline \multicolumn{3}{|c|}{ SRPC- $3 \%$ NS (SN3) } & 40.83 & \multicolumn{4}{|c|}{\begin{tabular}{|l|l|l|l|}
42.80 & 45.53 & 46.35 & 47.60 \\
\end{tabular}} \\
\hline \multicolumn{8}{|c|}{ Modulus of Elasticity $(\mathrm{GPa})\left(\mathrm{SO}_{4}^{--}\right)$} \\
\hline \multicolumn{3}{|c|}{ Mix Designation } & $\begin{array}{c}\text { Before } \\
\text { exposure } \\
\text { at } 28\end{array}$ & $\begin{array}{c}60 \\
\text { days }\end{array}$ & $\begin{array}{c}90 \\
\text { days }\end{array}$ & \begin{tabular}{|c}
120 \\
days
\end{tabular} \mid & $\begin{array}{l}180 \\
\text { days }\end{array}$ \\
\hline \multicolumn{3}{|c|}{ OPC- $0 \% \mathrm{NS}(\mathrm{OR})$} & 31.30 & 31.75 & 32.23 & 332.20 & 30.23 \\
\hline \multicolumn{3}{|c|}{ OPC- $3 \% \mathrm{NS}(\mathrm{ON} 3)$} & 39.00 & 40.00 & 42.19 & 942.80 & 42.01 \\
\hline \multicolumn{3}{|c|}{ SRPC- $0 \%$ NS (SR) } & 33.78 & 35.24 & 36.53 & 336.57 . & 736.30 \\
\hline \multicolumn{3}{|c|}{ SRPC- 3\%NS (SN3) } & 40.83 & 42.68 & 45.36 & 645.76 & 646.63 \\
\hline
\end{tabular}

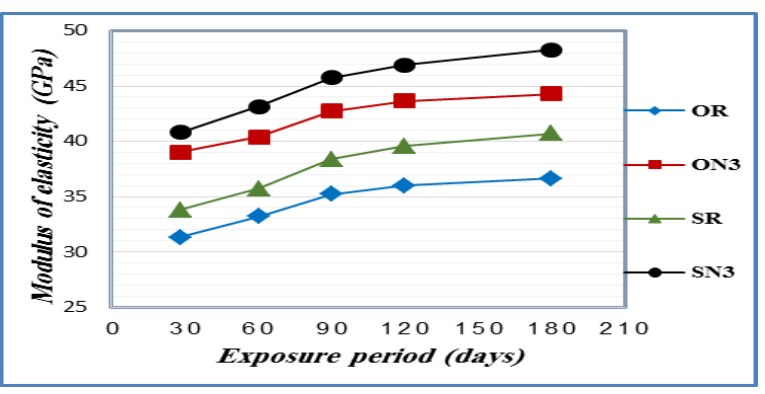

(a) Tap Water. 


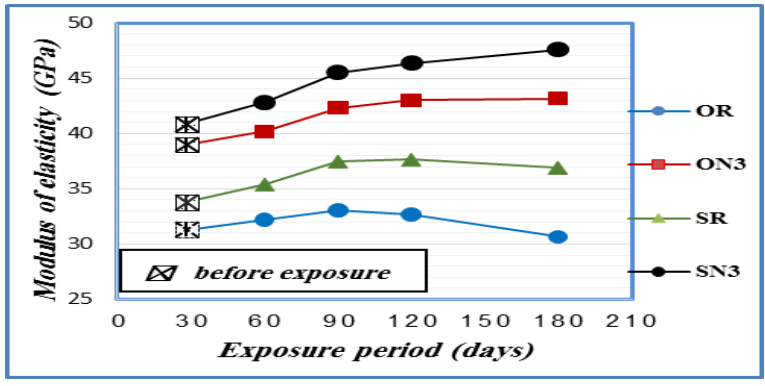

(b) $\left(\mathrm{SO}_{4}{ }^{--}+\mathrm{Cl}^{-}\right)$solution.

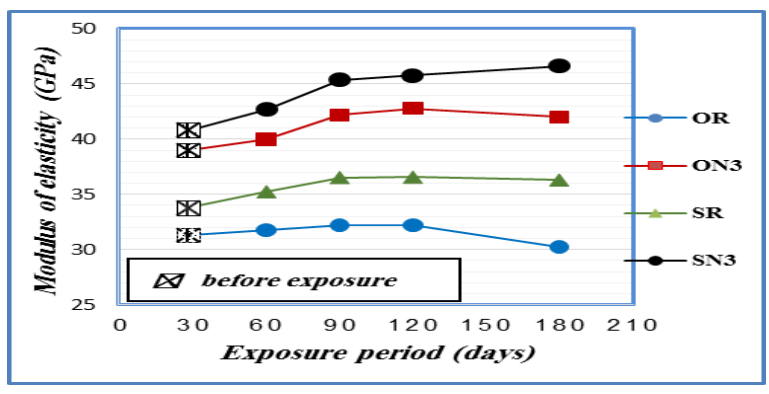

(c) $\left(\mathrm{SO}_{4}^{-{ }^{--}}\right)$solution.

Fig. 4. Modulus of Elasticity Development of SCC Mixes Exposed to various exposure conditions.

\subsection{Ultrasonic Pulse Velocity (U.P.V.)}

The results of U.P.V. test was measured on $150 \mathrm{~mm}$ cubes at different curing ages $(28,60,90,120$ and 180 days). These results are illustrated in Table (16) and Figures (5- a, b and c).

The results show that the U.P.V. for SCC cured in tap water exhibit a continuous increasing in U.P.V. with age progress. The recorded results of U.P.V. for SN3 ranged between $(5.321-5.837) \mathrm{km} / \mathrm{sec}$, ON3 ranged between (5.264-5.738) $\mathrm{km} / \mathrm{sec}$, SR ranged from (4.912-5.539) $\mathrm{km} / \mathrm{sec}$, and OR ranged from $(4.857-5.398) \mathrm{km} / \mathrm{sec}$. The behavior is mainly attributed to the increase in density of concrete with age progress. The same conclusion is reported by (Hadi, 2009). The test results also indicate that all SCC specimens subjected to pure sulfate or combined sulfate solution demonstrate a reduction in U.P.V. values at all exposure periods relative to corresponding SCC cured in tap water. Moreover, the SCC specimens exposed to pure sulfate solution elucidate more reduction in U.P.V. compared with combined sulfate solution. This reduction can be related to the formation of micro-cracks resulted by sulfate attack which formed with a large quantity in pure sulfate solution compared with combined sulfate solution, and these micro-cracks connecting to each other to form larger cracks over time due to exposure. In such a case, the pulse will be diffracted around the larger cracks, thereby increasing the travel path and travel time, leading to the decrease in pulse velocity. This is also reported by (Mahmoud, 2012) and (Kazem, 2013).

The U.P.V. values increase with adding of Nano Silica for all SCC mixes. This behavior may be attributed to the effect of Nano Silica Which increase the density and filled the pores of the cement matrix with new CSH gel, this makes the pulse velocity increases for SCC.
Table 16. Results of U.P.V. of SCC Mixes.

\begin{tabular}{|c|c|c|c|c|c|}
\hline \multicolumn{6}{|c|}{ U.P.V. $(\mathrm{km} / \mathrm{sec})$ (Tap water) } \\
\hline Mix & $\begin{array}{c}\text { Before } \\
\text { at } 28 \text { days }\end{array}$ & $\begin{array}{c}60 \\
\text { days }\end{array}$ & $\begin{array}{c}90 \\
\text { days }\end{array}$ & $\begin{array}{l}120 \\
\text { days }\end{array}$ & $\begin{array}{l}180 \\
\text { days }\end{array}$ \\
\hline $\begin{array}{c}\text { OPC- } 0 \% \mathrm{NS} \\
\text { (OR) }\end{array}$ & 4.857 & 5.067 & 5.245 & 5.325 & 5.398 \\
\hline $\begin{array}{c}\text { OPC- 3\%NS } \\
\text { (ON3) }\end{array}$ & 5.264 & 5.39 & 5.575 & 5.635 & 5.738 \\
\hline $\begin{array}{c}\text { SRPC- 0\%NS } \\
\text { (SR) }\end{array}$ & 4.912 & 5.229 & 5.386 & 5.463 & 5539 \\
\hline $\begin{array}{c}\text { SRPC- 3\%NS } \\
\text { (SN3) } \\
\end{array}$ & 5.321 & 5.543 & 5.698 & 5.759 & 5.837 \\
\hline \multicolumn{6}{|c|}{ U.P.V. $(\mathrm{km} / \mathrm{sec})\left(\mathrm{SO}_{4}^{--}+\mathrm{Cl}^{-}\right)$} \\
\hline Mix & $\begin{array}{c}\text { Before } \\
\text { at } 28 \text { days }\end{array}$ & $\begin{array}{c}60 \\
\text { days } \\
\end{array}$ & $\begin{array}{c}90 \\
\text { days }\end{array}$ & $\begin{array}{c}120 \\
\text { days }\end{array}$ & $\begin{array}{r}180 \\
\text { days }\end{array}$ \\
\hline $\begin{array}{c}\text { OPC- } 0 \% \mathrm{NS} \\
(\mathrm{OR})\end{array}$ & 4.857 & 5.050 & 5.165 & 5.174 & 5.154 \\
\hline $\begin{array}{c}\text { OPC- } 3 \% \mathrm{NS} \\
(\mathrm{ON} 3)\end{array}$ & 5.264 & 5.381 & 5.550 & 5.584 & 5.607 \\
\hline $\begin{array}{c}\text { SRPC- 0\%NS } \\
\text { (SR) }\end{array}$ & 4.912 & 5.217 & 5.296 & 5.383 & 5.394 \\
\hline $\begin{array}{c}\text { SRPC- 3\%NS } \\
\text { (SN3) }\end{array}$ & 5.321 & 5.537 & 5.667 & 5.727 & 5.745 \\
\hline \multicolumn{6}{|c|}{ U.P.V. $(\mathrm{km} / \mathrm{sec})\left(\mathrm{SO}_{4}^{--}\right)$} \\
\hline $\begin{array}{c}\text { Mix } \\
\text { Designation }\end{array}$ & $\begin{array}{c}\text { Before } \\
\text { exposure at } 28 \\
\text { days }\end{array}$ & $\begin{array}{c}60 \\
\text { days }\end{array}$ & $\begin{array}{c}90 \\
\text { days }\end{array}$ & $\begin{array}{l}120 \\
\text { days }\end{array}$ & $\begin{array}{l}180 \\
\text { days }\end{array}$ \\
\hline $\begin{array}{c}\text { OPC- } 0 \% \mathrm{NS} \\
\text { (OR) }\end{array}$ & 4.857 & 5.000 & 5.074 & 5.097 & 5.087 \\
\hline $\begin{array}{c}\text { OPC- 3\%NS } \\
\text { (ON3) }\end{array}$ & 5.264 & 5.375 & 5.467 & 5.532 & 5.542 \\
\hline $\begin{array}{c}\text { SRPC- 0\%NS } \\
\text { (SR) }\end{array}$ & 4.912 & 5.210 & 5.276 & 5.300 & 5.324 \\
\hline $\begin{array}{c}\text { SRPC- 3\%NS } \\
\text { (SN3) }\end{array}$ & 5.321 & 5.516 & 5.624 & 5.688 & 5.740 \\
\hline
\end{tabular}

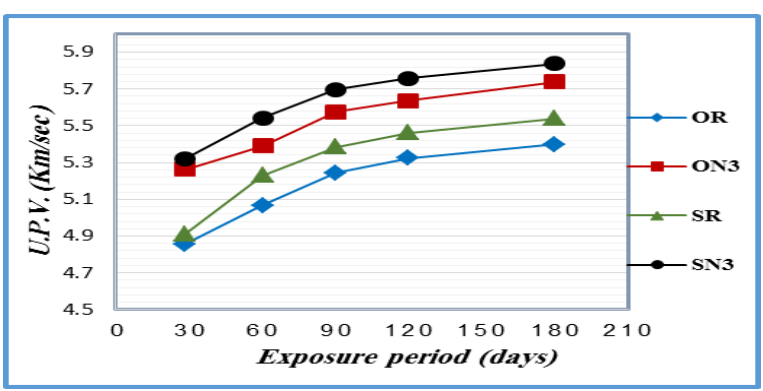

(a) Tap Water

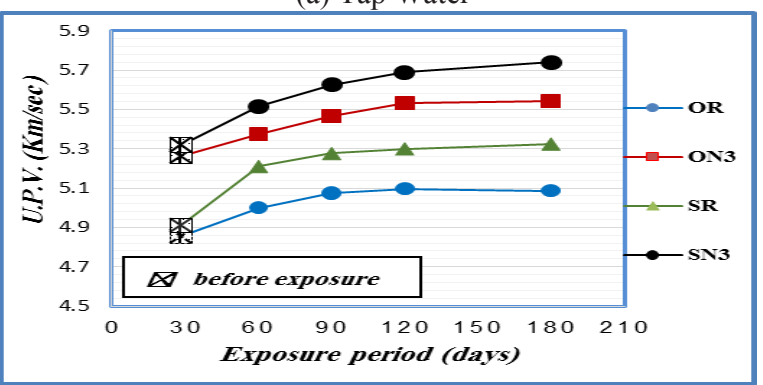

(b) $\left(\mathrm{SO}_{4}{ }^{--}+\mathrm{Cl}^{-}\right)$solution. 


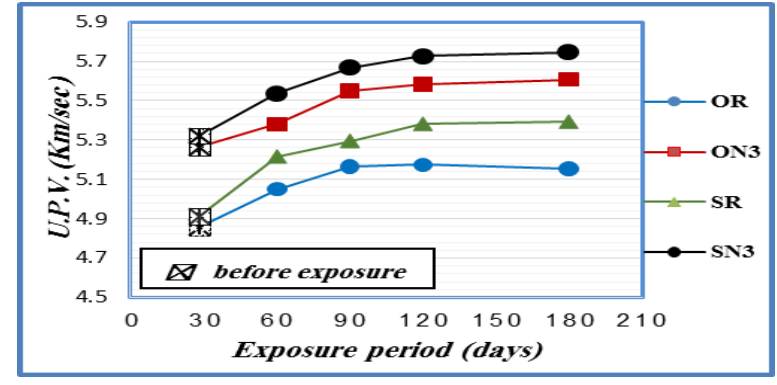

(c) $\left(\mathrm{SO}_{4}{ }^{-\cdots}\right)$ solution.

Fig. 5. U.P.V. Development of SCC Mixes Exposed to various exposure conditions.

\section{Conclusions}

-SCC specimens exposed to $\left(\mathrm{SO}_{4}{ }^{--}+\mathrm{Cl}^{-}\right)$or $\left(\mathrm{SO}_{4}{ }^{-{ }^{-}}\right)$ solution demonstrated a significant reduction in splitting tensile strength, flexural strength, modulus of elasticity and U.P.V. when compared with the specimens cured in tap water.

-The utilizing of 3\% Nano Silica as an addition by weight of cementitious materials was found to be effective in improving the resistance of SCC to external sulfate attack. Also, the using of Nano Silica was found to be more benefit in OPC than SRPC.

-The deterioration in the mechanical properties, nondestructive tests was higher in $\left(\mathrm{SO}_{4}^{-{ }^{-}}\right)$solution compared with $\left(\mathrm{SO}_{4}{ }^{--}+\mathrm{Cl}^{-}\right)$solution.

\section{References}

[1] Al-Amoudi, O. S., Maslehuddin, M., and Abdul-al, Y. A., (1995), Construction and Building Materials, Vol.9, Issue 1, February 1995, pp.(25-33).

[2] Al-Rawi R. S., (1985), ACI-RILEM, Joint Symposium, Monterey, Mexico, pp. 543.

[3] Asrar, N., Malik, A.U., Ahmad, S., and Andijani, I.N., (1997), Research and development center, presented in second acquired experience symposium on desalination plants, Sept. 29, 1997.

[4] ASTM C494/C494M, (2001), "Standard Specification for Chemical Admixtures for Concrete", American Society for Testing and Materials.

[5] European Project Group, (2005), "The European Guidelines for Self-Compacting Concrete: Specification, Production and Use", may, 2005, PP.63.

[6] Ganjian, E., and Pouya, H.S., (2005), Cement and Concrete Research, Vol. 35, pp. (1322-1343).
[7] Hadi, A.M., (2009), M.Sc. Thesis, University of Babylon.

[8] Iraqi Organization of Standards (IQS), No.45/1984, "Aggregate from Natural Sources for Concrete and Construction".

[9] Iraqi Organization of Standards (IQS), No.5/1984, "Portland Cement".

[10] Kazem, Z.H., (2013), M.Sc. Thesis, University of Babylon.

[11] Khanzadi, M., Tadayon, M., Sepehri , H., and Sepehri, M.,(2010), HBRC Journal, vol.20, No. 20, April 2010, p.p. (1-13).

[12]Li, G. (2004). Cement and Concrete Research, vol. 34, No.6, Jun. 2004, pp.(1043-1049).

[13]Mahmoud, R.H.A., (2012), M.Sc. Thesis, University of Babylon.

[14] Prasad, J., Jain, D.K., and Ahuja, A.K., (2006), Asian Journal of Civil Engineering, Vol. 7, No. 3 (2006), pp. (259-268).

[15] Qing, Y., Zenan, Z., Deyu, K. and Rongshen, C., (2007), Construction and Building Materials, Vol.21, No.3,2007, pp. (539-545).

[16] Quercia, G., Spiesz, P., Husken, G., \& Brouwers, J. (2012), In Proceedings of the International Congress on Durability of Concrete (ICDC 2012), (pp. 1821).

[17] Safiuddin, M. D., West, J.S., and Soudki, K.A., (2008), Journal of Applied Sciences Research, Vol.4, No. 12, pp. (1834-1840).

[18] Singh, S., and Thombre ,S., (2013) International Journal of Latest Research in Science and Technology , ISSN 2278-5299 , Vol.2 , Issue.2, April (2013) ,pp.(87-90).

[19] Sobolev, K. , Flores, I. and Hermosillo, R.,(2006), "Proceedings of ACI Session on, November 7, Denver, USA 2006, pp. (91-118). 